\title{
KULIAH KERJA LAPANG PLUS (KKLP)
}

STIE-STKIP YAPTI JENEPONTO ANGKATAN XXII

TAHUN AKADEMIK 2020/2021

DESA.PAITANA, KEC.TURATEA, KAB.JENEPONTO

(PERBAIKAN SARANA DAN PRASARANA DESA)

NAMA : Nurhawani Syarif

NIM : : 9173490410034

EMAIL : Nurhawanisyarif04@gmail.com

\section{BENTUK KEGIATAN}

Perbaikan sarana dan prasarana lapangan sepak bola dan tiang bendera dan kantor desa.

2. LOKASI

Lapangan sepak bola dan kantor desa Paitana.

3. HARI/TANGGAL DAN WAKTU

Pada hari Kamis, 17 September 2020.

4. PESERTA YANG DILIBATKAN

Mahasiswa (i)

Kepala desa Paitana (PLT)

* Aparat desa

* Masyarakat.

5. ALASAN DIADAKANNYA 
Untuk memudahkan masyarakat dalam melaksanakan kegiatan olahraga dan memudahkan aparat desa memasang bendera merah putih.

6. TUJUAN DAN MANFAAT

$>$ Tujuan

Untuk memudahkan masyarakat dalam kegiatan olahraga .

$>$ Manfaat

Untuk memperbaiki sarana dan prasarana desa (Lapangan).

\section{DESKRIPSI KEGIATAN}

Proses kegiatan adalah menyediakan alat dan bahan kemudian dilakukan pembuatan lubang untuk tiang, kemudian membentuk gawang menggunakan tiga potong besi hingga berbentuk gawang sepak bola . 